brazilianpoliticalsciencereview

ARTICLE

\title{
'Break-In Parties' and Changing Patterns of Democracy in Latin America*
}

\author{
Thomas Kestler \\ Julius-Maximilians-Univertität Würzburg, Germany \\ Juan Bautista Lucca \\ Universidade Nacional de Rosário, Argentina \\ Silvana Krause \\ Universidade Federal do Rio Grande do Sul, Brazil
}

\begin{abstract}
Although Lijphart's typology of consensus and majoritarian democracy can be regarded as the most widely used tool to classify democratic regimes, it has been rarely applied to Latin America so far. We try to fill this gap by adapting Lijphart's typological framework to the Latin American context in the following way. In contrast to previous studies, we treat the type of democracy as an independent variable and include informal factors such as clientelism or informal employment in our assessment of democratic patterns. On this basis, we aim to answer the following questions. First, how did the patterns of democracy evolve in Latin America over the two decades between 1990 and 2010 and what kind of differences can be observed in the region? Second, what are the institutional determinants of the observed changes? We focus on the emergence of new parties because of their strong impact on the first dimension of Lijphart's typology. From our observations we draw the following tentative conclusions: If strong new parties established themselves in the party system but failed to gain the presidency, they pushed the system towards consensualism. Conversely, new parties that gained the presidency produced more majoritarian traits.
\end{abstract}

Keywords: Break-in parties; types of government; Latin America; democracy; informality.

(*) http://dx.doi.org/10.1590/1981-38212016000100004

For replicating data, see bpsr.org.br/files/archives/Dataset_Kestler_Lucca_Krause This project has been made possible through the support of the Fritz Thyssen Foundation.

(2016) $10(1) \quad$ - $\quad$ e0004-1/31


A rend Lijphart's $(1999,2012)$ patterns of democracy can be regarded as the most influential and most widely accepted tool to classify democratic regimes. It is based on one central dimension, the degree of power dispersion or concentration, and on two polar types, majoritarian democracy and consensus democracy. In the course of empirical analysis the typology evolved into a twodimensional matrix, with a so called executive-parties dimension on the one hand and a unitary-federal dimension on the other. Ljiphart's $(1999,2012)$ original work was primarily concerned with classification. Insofar as theory building was undertaken, he treated the properties of democratic systems - their majoritarian or consensual characteristics - as independent variables and checked for their effects on governance and policy outcomes.

Lijphart's (1999, 2012) approach and measurement have been applied so far mainly to established democracies and OECD members (ARMINGEON, 2004; VATTER et al., 2013리 . As for Latin America, there has been little research based on this typology. This is probably due to the fact that Latin American democracies are different in several aspects from established Western ones. They exhibit a higher degree of instability, apparently from high rates of electoral volatility, comparatively frequent presidential impeachments and stronger political polarization. Furthermore, informal institutions, which are not explicitly covered by Lijphart, play a more important role in structuring political processes in Latin America (HELMKE and LEVITSKY, 2006²). Together, higher instability and stronger informality complicate typological assessment. Lijphart's framework, therefore, has to be adapted to the Latin American context in two respects: first, informal aspects have to be included into the operationalization of the defining variables, and second, more emphasis has to be put on aspects of institutional change by choosing shorter periods of assessment.

\footnotetext{
1 Exceptions to the rule are Fortin (2008) and Reynolds (1999). Amorim Neto (2009) replicates Lijphart's measurement for the case of Brazil with the same indicators and the same scales, which allows him to relate Brazil to the other cases in Lijphart's sample. Our purpose is different from Amorim Neto's (2009) insofar as we adapt Lijphart's indicators to the Latin American context. Despite this, however, his results for the case of Brazil largely confirm our observations. 2 The first dimension of Lijphart's framework is primarily concerned with behavioral patterns that partly reflect informal institutions, especially with respect to executive power-sharing and interest mediation. The impact of informality on his variables, however, is not discussed by Lijphart, and a range of phenomena like clientelism or personalism is not considered at all. The limited capacity of Lijphart's indicators to adequately describe political processes in Latin America is also pointed by Santos (2000).
}

(2016) $10(1) \quad$ - $\quad$ e0004-2/31


Changing institutional patterns has become a major concern in established democracies, too. In recent years, shifts between majoritarian and consensual patterns have been observed even in prototypical cases such as Switzerland and Great Britain (FLINDERS, 2010; VATTER, 2008). These institutional changes have moved the focus of investigation from categorization to theory-building and turned democratic patterns into a dependent variable. As a consequence, two main questions arise: What kind of institutional change is actually taking place (VATTER et al., 2013) and what are the driving forces behind changing institutional patterns?

Through an analysis of ten of the major Latin American countries, we will try to approach answers to both of these questions ${ }^{3}$. With regard to the first question, we take account of institutional changes during the past 20 years. We applied Lijphart's (1999, 2012) variables to our sample and made two measurements, one between 1990 and 1999, and a second one between 2000 and 2009. Given the dramatic political and economic changes that took place during those periods, we expected a shift in the patterns of democracy and aimed at determining the direction of this shift. Among the reasons for us to expect such a shift is the emergence of the so-called break-in parties ${ }^{4}$. Parties like the Partido dos Trabalhadores (PT) in Brazil, the Frente Amplio (FA) in Uruguay, FREPASO in Argentina or the Partido de la Revolución Democrática (PRD) in Mexico, to name just a few, took an impressive rise between 1990 and 2000 and 'broke into' party systems that for long had been dominated by traditional party machines dating back to the first half of the $20^{\text {th }}$ century. Due to these 'break-in' parties, the structure of Latin American party systems and thereby the structure of political competition changed fundamentally (LÓPEZ, 2005). How exactly this change has

\footnotetext{
3 The ten cases are Argentina, Bolivia, Brazil, Chile, Colombia, Ecuador, Mexico, Peru, Uruguay, and Venezuela. We restricted our sample to these cases, firstly to guarantee a certain degree of homogeneity, and, secondly, to facilitate qualitative assessment and contextualized interpretation of our results.

${ }_{4}$ The term break-in party is inspired by Katz and Mair (1995, p. 08), who describe the classical mass party as emanating from sectors of the electorate, with the intention of breaking into the state and modifying public policy in the long-term interest of the constituency to which it is accountable. This does not mean, however, that we equate break-in parties with mass parties. We define this type rather as new parties that are capable to 'break' into the party system and to change fundamentally the patterns of competition, the composition of elites, and the structure of representation (KESTLER et al., 2013). To identify break-in-parties, we used two criteria: first, the composition of the party leadership (the party leadership has to be composed at least partially by outsiders without access to the state); second, rejection of the status quo (the party has to be, in programmatic terms, opposed to the status quo). The corresponding parties we identified on this ground are to be found in the annex.
} 
proceeded is an issue that has to be substantiated by a closer look at the dimensions and variables of Lijphart's $(1999,2012)$ typology.

The relationship between break-in parties and patterns of democracy is far from straightforward. In general, causality can be assumed in both directions, with break-in parties as the dependent or the independent variable. We assume, however, that the first of Lijphart's $(1999,2012)$ two dimensions is more clearly influenced by the emergence of break-in-parties, while the second dimension, especially the federal or unitary character of the state, should rather be treated as an independent variable. The aim of this article is to provide the foundation for further research about this relationship. For a first approximation, we restrict our analysis to the first of the two possible perspectives: Break-in parties are treated as independent variables and their impact is discussed with regard to the executives-parties dimension only. For this purpose, we put forward the following hypothesis: If strong break-in parties established themselves in the party system but failed to gain the presidency, they pushed the system towards consensualism. Conversely, break-in parties that gained the presidency produced more majoritarian traits.

In the following section we assess the development of democracy in Latin America during the past two decades by applying the first five variables of Lijphart's $(1999,2012)$ typological toolbox. In the second part, we include informal patterns in the measurement and present the respective findings for our two periods of observation. In the third section we discuss the hypothesis about the impact of break-in parties on democratic patterns on the basis of our findings.

\section{Patterns of democracy in Latin America between 1990 and 2009}

If we look at Latin America at the start of the 1990s and again 20 years later, we observe two quite different places. Gross domestic product has quadrupled in this period; the region has seen the rise of outsiders like Alberto Fujimori, Hugo Chávez, Evo Morales or Rafael Correa (LEVISTKY and ROBERTS, 2011). Far reaching reforms have been undertaken in the fields of decentralization, justice, finance or public administration (LORA, 2007). Several countries reformed their constitutions or replaced them altogether (NOLTE and SCHILLING-VACAFLOR, 2012). Thus, we can reasonably assume that those developments left their mark on the patterns of democracy, but, 
without a closer look at their components, it is difficult to hypothesize about the kind and causes of the aforementioned changes.

Given the fact that our focus is on political parties, we restrict our analysis to the executive-parties dimension of Lijphart's $(1999,2012)$ framework that is concerned with actors and behavior. Lijphart's (1999, 2012) factor analysis shows a strong correlation between the structure of the party system and the executives-parties dimension, while there is only weak correlation with the second factor, representing the federal-unitary-dimension (LIJPHART, 1999, p. 246). Furthermore, the second dimension covers formal constitutional structures that are more resilient and change only incrementally 5 . To observe the impact of break-in parties on democratic patterns, it seems appropriate to look at the more malleable first dimension. This first dimension includes patterns of inclusion and power division on the level of the party system, the executive, the parliament, the electoral system, and interest representation. It comprises five variables: 1) Two-Party vs. Multiparty Systems; 2) Concentration vs. Sharing of Executive Power; 3) Executive-Legislative Relations; 4) Majority vs. Proportional Electoral Systems; and 5) Interest Group Pluralism vs. Corporatism.

While structured by institutional rules and incentives, this dimension is strongly shaped by actors - their power, interests and behavior. Because of this, it is especially sensitive to the emergence of break-in parties that affect directly the first, second and third variables. To convert the five variables into indicators and to assess them for our ten cases, we relied as far as possible on Lijphart's $(1999,2012)$ operationalization. With regard to scaling, we departed from Lijphart $(1999,2012)$ and followed the example of Reynolds (1999), who applied uniformly a five-point scale for all variables in his analysis of South African countries. We used a scale ranging from 01 (most majoritarian) to 05 (most consensual) for each of the ten variables. The scale is defined through the maximum and the minimum values observed in our sample. Quantitative measures are transformed correspondingly. In some cases we had to adapt the indicators, fitting them to context and data.

\footnotetext{
${ }^{5}$ During the period of observation, the average net change observed in the first dimension was $9.6 \%$ while in the second dimension it was only $4.8 \%$. Including informality, the respective values are $9.6 \%$ and $6.2 \%$.
}

(2016) $10(1) \quad$ - $\quad$ e0004-5/31 


\section{Variable 01: party system (two-party system vs. multiparty system)}

The party system variable captures the degree of power dispersion or concentration on the level of the party system, measured by the effective number of parliamentary parties as calculated by Laakso and Taagepera (1979). According to Lijphart (1999): "[T]wo-party systems typify the majoritarian model of democracy and multiparty systems the consensus model" (LIJPHART, 1999, p. 63). For Latin America, we have additionally accounted for one-party systems because some systems, such as Mexico until 1988 or Venezuela under Chavista hegemony, approached this type.

The impact of break-in parties on the party system is quite apparent: the effective number of parties in our ten cases went from an average of 3.4 between 1980 and 1989 to 4.3 during the 1990 s, and to 4.5 in the years 2000 to $2009^{6}$. On the level of the party system, therefore, a process of pluralization took place. The bi-partisan or oneparty pattern, which had prevailed in many countries until the 1980s, has been replaced by multi-party systems corresponding to a consensus type of democracy. Despite the overall tendency towards pluralization, however, developments in the countries of the region diverged significantly (see Table 01). A group of countries composed of Ecuador, Chile and Brazil, is marked by multiparty systems that more or less maintained their pluralist (or fragmented) character during the period of observation. Colombia moved from a strong bipartyism to a pluralist pattern. By contrast, Uruguay, Venezuela and Bolivia took the opposite direction from multipartyism during the 1990s to concentration in the 2000s. This development was especially pronounced in Venezuela, where the effective number of parliamentary parties became nearly one between 2005 and 2009. And, finally, a group of countries composed of Peru, Mexico, and Argentina displays a moderate degree of pluralization that increased slightly during the second period. Obviously, in some cases break-in parties accentuated the pluralistic structure of the party system, while in others a process of re-concentration set in during the 2000s, due either to the failure and disappearance of break-in parties or to the collapse of established parties (SEAWRIGHT, 2006).

\footnotetext{
6 Calculated with the data from Alcántara (2012) and OPAL (http://americo.usal.es/oir/opal/indicadores.htm); see also Paine (2007).
} 
Table 01. Effective number of parties and scores for the 1990s and 2000s

\begin{tabular}{|c|c|c|c|c|}
\hline & \multicolumn{2}{|c|}{ Effective Number of Parliamentary Parties } & \multicolumn{2}{|c|}{ Score Scale* } \\
\hline & $1990 \mathrm{~s}$ & $2000 \mathrm{~s}$ & $1990 \mathrm{~s}$ & $2000 s$ \\
\hline Argentina & 3.1 & 3.7 & 02 & 03 \\
\hline Brazil & 8.0 & 9.0 & 05 & 05 \\
\hline Bolivia & 4.5 & 3.4 & 03 & 02 \\
\hline Chile & 5.1 & 5.7 & 04 & 05 \\
\hline Colombia & 2.7 & 7.2 & 02 & 05 \\
\hline Ecuador & 5.8 & 5.7 & 05 & 05 \\
\hline Mexico & 2.5 & 3.0 & 01 & 02 \\
\hline Peru & 3.5 & 4.0 & 02 & 03 \\
\hline Uruguay & 3.2 & 2.5 & 02 & 01 \\
\hline Venezuela & 5.2 & 1.9 & 04 & 01 \\
\hline
\end{tabular}

\section{Variable 02: concentration vs. sharing of executive power}

The second variable describes "the breadth of participation by the people's representatives in the executive branch of the government" (LIJPHART, 1999, p. 90). It:

...can be regarded as the most typical variable in the majoritarian-consensus contrast: the difference between one-party majority governments and broad multiparty coalitions epitomizes the contrast between the majoritarian principle of concentrating power in the hands of the majority and the consensus principle of broad power-sharing (LIJPHART, 1999, p. 90).

On the one side, we find one-party majority cabinets of the minimum-winning type that mark the extreme majoritarian pole and, on the other, the consensual side, the oversized multi-party type of cabinets. Measurement is based on size (minimumwinning or oversized) and composition (one-party or multi-party) of cabinets as well as the average duration of the different cabinet types over time.

Classifications and theories on cabinet types and coalitions have been developed for parliamentary systems. In the case of the presidential systems that prevail in Latin America, Lijphart $(1999,2012)$ suggests modifications. Given the fact that in presidential systems executives are directly elected by majority rule, they always correspond to the one-party-minimum type. With respect to parliamentary support and cabinet membership, however, different kinds of coalitions are possible. Lijphart (1999, 2012) proposes to weight the majoritarian character of presidential system by $50 \%$ and to calculate the remaining $50 \%$ according to the breadth of legislative support and 
cabinet composition (LIJPHART, 1999, pp. 105-106). Because all of our cases belong to the presidential type, measurement is based solely on cabinet composition and coalition politics.

One typical feature of Latin American political systems is the combination of presidentialism and multi-party legislatures (MAINWARING, 1993). Most of the time, presidents confront a multi-party legislature and therefore have to rely on specific strategies for governing, including more or less formal parliamentary coalitions and different parties in cabinets (AMORIM NETO and SAMUELS, 2010), with the Brazilian 'presidencialismo de coalizão' being the most notable and institutionalized case (ABRANCHES, 1988; POWER, 2010). Indeed, with the exception of Paraguay, all Latin American countries experienced at least one period of coalition government (ALEMÁN and TSEBELIS, 2011; RUIZ VALERIO, 2008). In recent decades, this pattern appears to be on the rise. With the growing number of parties, coalition governments became more common in Latin America, especially during the 1990s. This tendency towards parliamentary coalitions and multi-party cabinets allows for an assessment of executive power-sharing similar to parliamentary systems ${ }^{7}$. The scores for all countries are displayed in Table 02. The extreme majoritarian type of one-party rule is exemplified by Mexico during the 1990s, while Brazil represents an extreme case of executive power sharing.

Table 02. Scores for the second variable, 1990s and 2000s

\begin{tabular}{lcccccccccc}
\hline & Arg & Bol & Bra & Chi & Col & Ecu & Mex & Per & Uru & Ven \\
\cline { 2 - 9 } 1990s & 02 & 03 & 05 & 05 & 03 & 03 & 01 & 02 & 03 & 04 \\
2000s & 04 & 02 & 05 & 03 & 03 & 03 & 03 & 03 & 02 & 02 \\
\hline
\end{tabular}

Source: Elaborated by authors based on Albala (2009) and Altman (2009).

Note: Scale Score: 01 = most majoritarian; 05 = most consensual.

A comparison between the first and the second period reveals divergent developments. Patterns of power-sharing remained unchanged in Brazil, Colombia and Ecuador, but changed in Bolivia, Uruguay, Chile and Venezuela, where a move towards power concentration took place. Peru, Argentina and Mexico, on the other hand, moved

\footnotetext{
${ }^{7}$ We based our measurement on the data provided by Altman and Castiglioni (2009) and Albala (2009) and complemented them in some cases by additional qualitative sources.
}

(2016) $10(1) \quad$ - $00004-8 / 31$ 
towards consensualism ${ }^{8}$. This is remarkable insofar, as break-in parties appeared in Venezuela, as well as in Argentina and Mexico. In the first case, the subsequent development took the direction of majoritarianism, while in the latter cases consensualism has been strengthened. It should be noted that executive power sharing correlates strongly with the first variable, the effective number of parties ${ }^{9}$. This correlation is observable in Bolivia, Uruguay, Mexico, Argentina, Peru and Venezuela, but not in Colombia.

\section{Variable 03: executive-legislative relations}

In Lijphart's $(1999,2012)$ typology, the "majoritarian model is one of executive dominance, whereas the consensus model is characterized by a more balanced executive-legislative relationship" (LIJPHART, 1999, p. 116). To measure this variable, however, major adaptations are necessary. The indicator used by Lijphart $(1999,2012)$ - cabinet duration - is applicable only to parliamentary systems that make for the largest part of his sample. In the case of presidential systems, it proves to be largely useless.

Presidentialism is one of the few institutional constants of Latin American political systems. Nonetheless, it is still far from being an unequivocal concept. Presidential governments differ with regard to the constitutional and partisan powers at the disposal of the executive (MAINWARING and SHUGART, 1997), as well as government styles and relations to other constitutional branches (MORGENSTERN and NACIF, 2002). To grasp the relations between executives and legislatures, we relied on the assessment of presidential powers by Shugart and Carey (1992) for the first period, and the assessment of legislatures by Fish and Kroenig (2009) for the second period. Also, to measure the partisan powers of presidents, we used provisions for presidential term limits as a complementary criterion, supposing that presidents who can run for a second term or even indefinitely are in a stronger position than one-term presidents. We adapted the aforementioned data correspondingly in cases where formally weak presidents enjoyed the right for reelection or vice versa. The scores are shown in Table 03.

\footnotetext{
8 In Mexico, the higher score is due to minority one-party cabinets after 2000 that are located in the middle of the scale by Lijphart (1999).

${ }^{9}$ The correlation coefficient is .794 for the first and .591 for the second period of observation.
} 
Table 03. Scores for the third variable, 1990s and 2000s

\begin{tabular}{lcccccccccc}
\hline & Arg & Bol & Bra & Chi & Col & Ecu & Mex & Per & Uru & Ven \\
\cline { 2 - 9 } 1990s & 03 & 03 & 02 & 02 & 03 & 04 & 03 & 03 & 03 & 04 \\
2000s & 03 & 03 & 02 & 02 & 03 & 03 & 03 & 03 & 03 & 02 \\
\hline
\end{tabular}

Source: Elaborated by the authors on Shugart and Carey (1992), Fish and Kroenig (2009) and PNUD (2004).

Note: Scale Score: 01 = most majoritarian; 05 = most consensual.

Because this variable is assessed mainly by formal constitutional indicators, little variation can be observed from the first period to the second. Most countries are located in the middle of the scale, reflecting the checks and balances typical for presidential systems. Supposedly, stronger differences appear when informal aspects are included, given the fact that presidential power in Latin America is based, to a considerable degree, on informal means.

\section{Variable 04: electoral systems}

The fourth variable is concerned with majoritarian or consensual characteristics on the level of the electoral system. Electoral systems serve to transform votes into mandates, in a way which depends on their design. Electoral rules influence the party system in the following way: Plurality rule in single-member districts lead to two-party systems; proportionality rule favors the emergence of multiparty systems. Proportionality, therefore, encourages the dispersion of power, whereas majority or plurality rules lead to concentration (POWELL, 2000). Between the extreme poles of single-member plurality rule and perfect proportionality, electoral systems display a great variety and allow for different degrees of concentration or dispersion. These degrees correspond largely to the size of electoral districts. Small districts correspond to a majoritarian logic, large districts to a consensual one. In addition to district size, there is a wide range of factors that influence the functioning and effects of electoral systems. Because of the resulting complexity, measurement and comparison are not based on electoral rules, but on the degree of disproportionality an electoral system produces. Disproportionality describes the divergence between vote shares and mandates as calculated by Gallagher (1991). The Gallagher (1991) index of disproportionality is used by Lijphart $(1999,2012)$ to assess the majoritarian or consensual traits of electoral 
systems. High disproportionality corresponds to a majoritarian logic, low disproportionality to a consensual one.

This measure applies well to parliamentary systems. In presidential systems, with divided powers and two separate sources of electoral legitimation, the question arises about which election, legislative or presidential, should be considered. Presidential elections are majoritarian by nature and as such involve a high degree of disproportionality. Furthermore, presidential elections are usually regarded as the most important ones compared to legislative elections. To assess the presidential systems in his sample, Lijphart $(1999,2012)$ used the geometric mean of disproportionality in legislative and presidential elections. We took up this suggestion and calculated the degree of disproportionality for our sample accordingly (see Table 04).

Table 04. Electoral disproportionality and scores for the fourth variable, 1990s and 2000 s

\begin{tabular}{lcccc}
\hline & \multicolumn{2}{c}{$\begin{array}{c}\text { Disproportionality in legislative } \\
\text { and presidential elections } \\
\text { (geometric mean) }\end{array}$} & \multicolumn{2}{c}{ Score Scale* } \\
\cline { 2 - 5 } Argentina & $1990 \mathrm{~s}$ & $2000 \mathrm{~s}$ & $1990 \mathrm{~s}$ & $2000 \mathrm{~s}$ \\
\cline { 2 - 5 } Brazil & 27.75 & 27.24 & 01 & 01 \\
Bolivia & 12.63 & 11.79 & 04 & 04 \\
Chile & 16.59 & 13.89 & 03 & 03 \\
Colombia & 18.56 & 18.36 & 02 & 03 \\
Ecuador & 13.22 & 11.88 & 04 & 04 \\
Mexico & 17.35 & 15.00 & 03 & 03 \\
Peru & 16.17 & 22.56 & 03 & 02 \\
Uruguay & 11.85 & 17.97 & 04 & 03 \\
Venezuela & 4.98 & 10.03 & 05 & 02 \\
\hline Source: & 15.47 & 19.44 & 03 & 04 \\
\hline
\end{tabular}

Source: USAL (http://americo.usal.es/oir/opal/indicadores.htm) and own calculation with the data from Nohlen (2005).

Note: $(*)$ Scale Score: 01 = most majoritarian; $05=$ most consensual.

There is a broad array of rules for electing legislatures in Latin America. The most usual type, however, is the proportional system with closed lists. In our sample, open lists are used only in Brazil and Ecuador, and a segmented electoral system is in place in Mexico. Another exception is Chile, where plurality rule in two-member districts is applied. However, in general, parliamentary elections in Latin America are marked by comparatively low degrees of disproportionality and allow for broad representation. In 
this regard, Uruguay is the most consensual case, due to its pure proportional electoral system and large electoral districts. Higher degrees of disproportionality can be found in Argentina, Ecuador or Chile, which are marked by comparatively small districts of between two and five mandates. Taking into account the disproportional effects of presidential elections, the overall values are significantly increased and approach the levels of plurality systems like the UK.

Electoral systems are usually stable or change only marginally (NOHLEN, 2005). This is true for Latin America, too, where most systems remained largely unchanged during our period of observation. As far as reforms were introduced, as in Bolivia in 1996, they aimed at a personalization of the vote, similar to the German system, but left the overall proportional logic of the electoral system in place. Nonetheless, there are exceptions like Venezuela, where a system of parallel voting was introduced ahead of the 2010 legislative elections, which increased significantly the disproportionality of the electoral system. In Mexico, the degree of disproportionality was increased by narrower results in presidential elections, reflecting the changes in the party system and the stronger polarization after the year 2000.

\section{Variable 05: interest groups - pluralism vs. corporatism}

Majoritarian or consensual traits can also be observed at the level of interest representation and organization. Lijphart $(1999,2012)$ states that majoritarian systems correspond to a pluralistic logic of interest representation while (neo-)corporatism is found in consensual democracies. Albeit the relationship between neo-corporatism and the four other components of consensus democracy included in the executive-parties dimension is not apparent at first glance, Lijphart $(1999,2012)$ shows that there are strong correlations between the kind of interest group representation and organization, on the one hand, and the voting system, party system and executive strength, on the other hand (LIJPHART,1999; LIJPHART and CREPAZ, 1991).

In Latin America, the era of corporatism set in with the turn to import substitution (ISI) and the emergence of national-revolutionary parties in the 1940s. The most notable and successful of them - the Partido Justicialista (PJ) in Argentina, Acción Democrática (AD) in Venezuela and the Partido de la Revolución Institucionalizada (PRI) in Mexico - relied heavily on strong, centralized unions for mobilization and integration. With the crisis of ISI, union membership declined and the foundations of corporatism 
eroded. By the 1990s, unionization rates had already fallen significantly compared to the 1970s or 1980s. In Argentina and Venezuela, unionization rates had fallen by over $40 \%$ between 1986 and 1995 (CARDOSO, 2001). So, the degree of pluralism (defined by Siarroff as the absence of corporatism ${ }^{10}$ ) had already increased strongly in our first period of observation ${ }^{11}$. Our assessment, therefore, starts from a low baseline.

With regard to measurement, we encountered the problem that the data used by Lijphart $(1999,2012)$ - the index of corporatism by Alan Siaroff (1999) - is not available for Latin America. Most of our cases are not covered by Siaroff's (1999) index and it is also difficult to replicate the measurement due to incomplete data on items such as unionization rates, number of unions or collective bargaining. We combined the available data from ILO and CEPAL on unionization rates, the total number of unions, the share of industrial workers on total employment, the size of the public sector and the number of strikes in order to approach an estimate for the countries in our sample. Additionally, we used the evaluation of collective bargaining types by O'Connell (1999). Given the uneven database, we had to rely on the data available for each of our cases. Table 05 shows the resulting scores.

Table 05. Scores for the fifth variable, 1990s and 2000s

\begin{tabular}{ccccccccccc}
\hline & Arg & Bol & Bra & Chi & Col & Ecu & Mex & Per & Uru & Ven \\
\cline { 2 - 11 } 1990s & 05 & 03 & 03 & 02 & 02 & 03 & 04 & 03 & 03 & 04 \\
2000s & 05 & 03 & 03 & 01 & 02 & 02 & 03 & 02 & 04 & 02 \\
\hline Source: & Elaborated & by & the & authors & based & on & O'Connell & (1999), & CEPAL
\end{tabular}
(http://estadisticas.cepal.org/cepalstat/WEB_CEPALSTAT/estadisticasIndicadores.asp?idioma= e) and OIT $(1998,2012)$.

Note: Scale Score: 01 = most majoritarian; 05 = most consensual.

10 Siaroff (1999) defines corporatism as follows: "let us note the main features of the concept of (liberal) corporatism at the national level as reflecting: within an advanced industrial society and democratic polity, the coordinated, co-operative, and systematic management of the national economy by the state, centralized unions, and employers (these latter two co-operating directly in industry), presumably to the relative benefit of all three actors. If this is taken to be the core definition of corporatism, then its opposite, (the lack of such coordinated and cooperative management), may generally be defined as 'pluralism'" (SIAROFF, 1999, p. 177).

${ }^{11}$ In his 2012 version, Lijphart $(1999,2012)$ measures pluralism across the whole period from 1945 to 2010. At least for his Latin American cases, such an aggregated measure runs over crucial developments and cannot be regarded as a valid indicator for the type of interest group system.

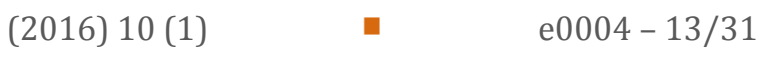


Albeit starting from an already low level of corporatist integration during the 1990s, values decreased even further during the second period in Chile, Ecuador, Peru and Venezuela. Only Uruguay raised its level, due to closer involvement of unions in government decision ${ }^{12}$.

Figure 01. Variation of aggregated scores for the first dimension between the 1990s and the 2000s in percent

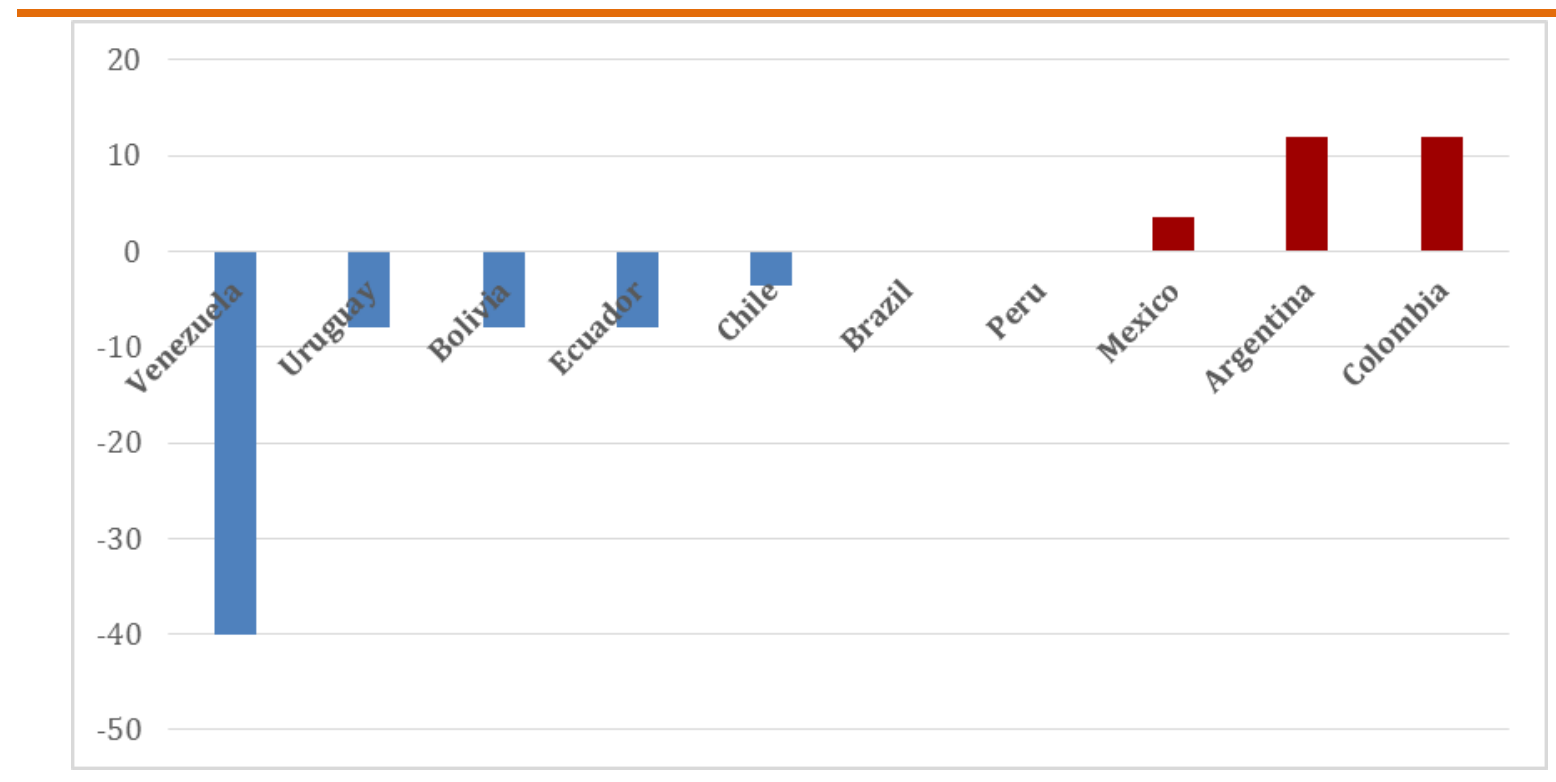

Source: Elaborated by the authors based on Alcántara (2012); Albala, A. (2009); Altman \& Castiglioni (2009); Fish and Kroenig (2009); Nohlen (2005); O'Connell (1999); Paine (2007); PNUD (2004); Shugart and Carey (1992). Datasets: OPAL (http://americo.usal.es/oir/opal/indicadores.htm);USAL(http://americo.usal.es/oir/opal/indic adores.htm);

CEPAL (http://estadisticas.cepal.org/cepalstat/WEB_CEPALSTAT/estadisticasIndicadores.asp?idioma= e); OIT $(1998,2012)$ and Latinobarometro (http://www.latinobarometro.org/).

The aggregate variations (expressed in percentages) within the first dimension over the period of assessment yield a mixed picture (Figure 01). While some countries (Colombia, Argentina and Mexico) moved towards consensualism, the larger part of the region (Venezuela, Uruguay, Bolivia, Ecuador and Chile) turned more majoritarian compared to the 1990s, albeit mostly by moderate degrees. A third group of countries (Peru and Brazil) remained stable and display no variation at all the aggregate level. Before we turn to our interpretation of these results and the role of break-in parties in the observed developments, we shall discuss the impact of informal factors and present

12 The government of Tabaré Vázquez decided in 2008 to include union representatives into the administration of health and education. 
a modified measurement, including indicators for informality. As already mentioned above, contextual factors and informal behavior potentially alter the functioning of institutional systems in Latin America and have to be taken into account in the assessment of democratic patterns.

\section{Patterns of democracy and informality}

The working of democracy in Latin America is strongly influenced by personal relations, elite networks and particularism, broadly subsumable under the category of informal institutions ${ }^{13}$. Although informality is implicitly covered by Lijphart's (1999, 2012) variables, too, especially in the first dimension, it has a different quality in Latin America, where informal institutions play a much more important role in structuring political interaction. Helmke and Levitsky (2006) define informal institutions as "socially shared rules, usually unwritten, that are created, communicated, and enforced outside officially sanctioned channels. By contrast, formal institutions are rules and procedures that are created, communicated, and enforced through channels that are widely accepted as official" (HELMKE and LEVITSKY, 2006, p. 05). Although informality is strongly idiosyncratic in nature, there are informal patterns that can be observed across the region. While certain informal practices like corruption affect not the patterns of democracy, properly, but rather the overall quality of democracy, others like personalism and informal employment influence the functioning of democracy without necessarily damaging its quality. We are concerned with the latter kind of informal practices and will discuss them in relation to our variables.

One important informal factor is clientelism. Clientelistic relations are problematic in terms of democratic quality, but they affect the functioning of the party system, too. Clientelism undermines the programmatic linkages of political parties and thereby reduces the effective political alternatives available to voters (KITSCHELT, 2000; KITSCHELT and WILKINSON, 2009). Widespread clientelism, therefore, affects the quality and the representational character of the party system. Under conditions assumed by Lijphart $(1999,2012)$, a high effective number of parties corresponds to a comparatively high number of issue dimensions represented in the party system. Pointing to Taagepera and Grofman (1985), Lijphart $(1999,2012)$ asserts that the

13 Not every informal kind of behavior and interaction should be regarded as an informal institution. The institutionality of such behavioral patterns depends on their durability and sanctionability (LAUTH, 2012).

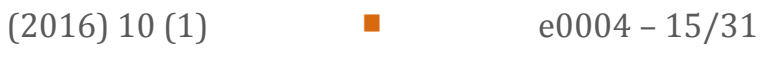


number of issue dimensions represented in a party system corresponds to the effective number of parties minus one (LIJPHART, 1999, p. 89). He states that the number of parties and the number of cleavages represented in a party system are so closely related that the latter does not have to be measured separately. In Latin America, however, such a close relationship between cleavages and the number of parties cannot be taken for granted because clientelism subverts programmatic representation. Clientelistic linkages, prevailing in many Latin American party systems, allow for a huge number of parties to exist without representing issue dimensions. Insofar, we can expect a negative relationship between clientelism and representation: the stronger the impact of clientelism on the party system, the fewer issue dimensions are represented. To get a more realistic picture of democratic patterns, therefore, we include clientelism in the assessment of the first variables. The values obtained by the implementation of Lijphart's $(1999,2012)$ indicator - the effective number of parliamentary parties - is discounted by the degree of clientelism as indicated by respondents to the Latinobarómetro survey ${ }^{14}$.

Variable two, the composition of the executive, needs no further modification because informality is covered sufficiently by Lijphart's (1999-2012) original indicator. This does not apply to variable three, which captures the relationship between legislature and executive. Experience shows that inter-institutional relations depend on informal sources of power such as the president's influence on nominations and his/her personal appeal on voters, which produces coattail-effects in parliamentary elections (MAINWARING and SHUGART, 1997). The stronger the personal prestige and the political leverage of the president, the more the institutional balance will shift in favor of the executive. To assess the strength of the president we used the results obtained by the Latinobarómetro poll for the question 'Who is most powerful'. This item reflects informal power resources on part of a president like the personalization of elections, the personal appeal through media coverage or personal authority in relation to his/her party. The more powerful a president is regarded by citizens, the more the patterns of

\footnotetext{
${ }^{14}$ The corresponding question is: "Conoce Ud. personalmente un caso en que una persona haya recibido privilegios por ser simpatizante del partido de gobierno?" ("Do you personally know any case of a person who has received any kind of privilege for being a sympathizer of the party in power?") (LATINOBARÓMETRO, 2005, pp. 29-30). Avaliable at http://www.latinobarometro.org/.
} 
democracy tend towards majoritarianism, leading in extreme cases to a defective type of democracy that cannot be classified along the patterns of democracy anymore.

Variable four - the electoral system - also requires closer inspection. Similarly to variable one, the relationship between proportionality and consensus democracy rests on the assumption of representational linkages, based on party identifications and issue orientations. This cannot be taken for granted in Latin America. Higher degrees of electoral volatility point to stronger personalization and more informal linkages between voters and officials. We assume that consensus democracy is predicated on the representation of societal interests through proportional representation. Only if elites are connected to citizens by representational linkages does proportionality lead to broad societal power sharing. If, by contrast, representational linkages are weak, proportional representation is restricted to elites. Elections take on a more majoritarian character because short term effects are stronger and shifts in power are more pronounced. We therefore adapt our measurement accordingly, by including volatility as an additional indicator for variable four.

And, finally, modifications are also required for variable five, the degree of pluralism or corporatism. Corporatism in its classical form is defined as a "system of representation and a process of policy making" (MOLINA and RHODES, 2002, p. 310) in the sphere of labor relations, especially in industry. In Latin America, this sphere was much more restricted due to the smaller share of industrial workers on formal employments and, additionally, the existence of a large informal sector. During the economic crisis of the 1980 s and 1990 s, the informal sector grew to over $50 \%$ in many Latin American countries. Under such conditions, corporatist structures of interest mediation only extended to a small, if any, share of total employment. We, therefore, include informality of labor relations into our measurement of variable four. To this end, the scores for corporatism were adjusted taking into account the size of the informal sector.

Given the fact that all of the additional indicators for informality enhance the tendency towards majoritarianism, we expect the average values to decrease. If we calculate the difference between the country value and the midpoint of our scale, we can observe the tendencies in our ten cases during both periods of assessment. 
Figure 02. Consensual and majoritarian tendencies during the 1990s (deviation from the midpoint of the scale, in percent)

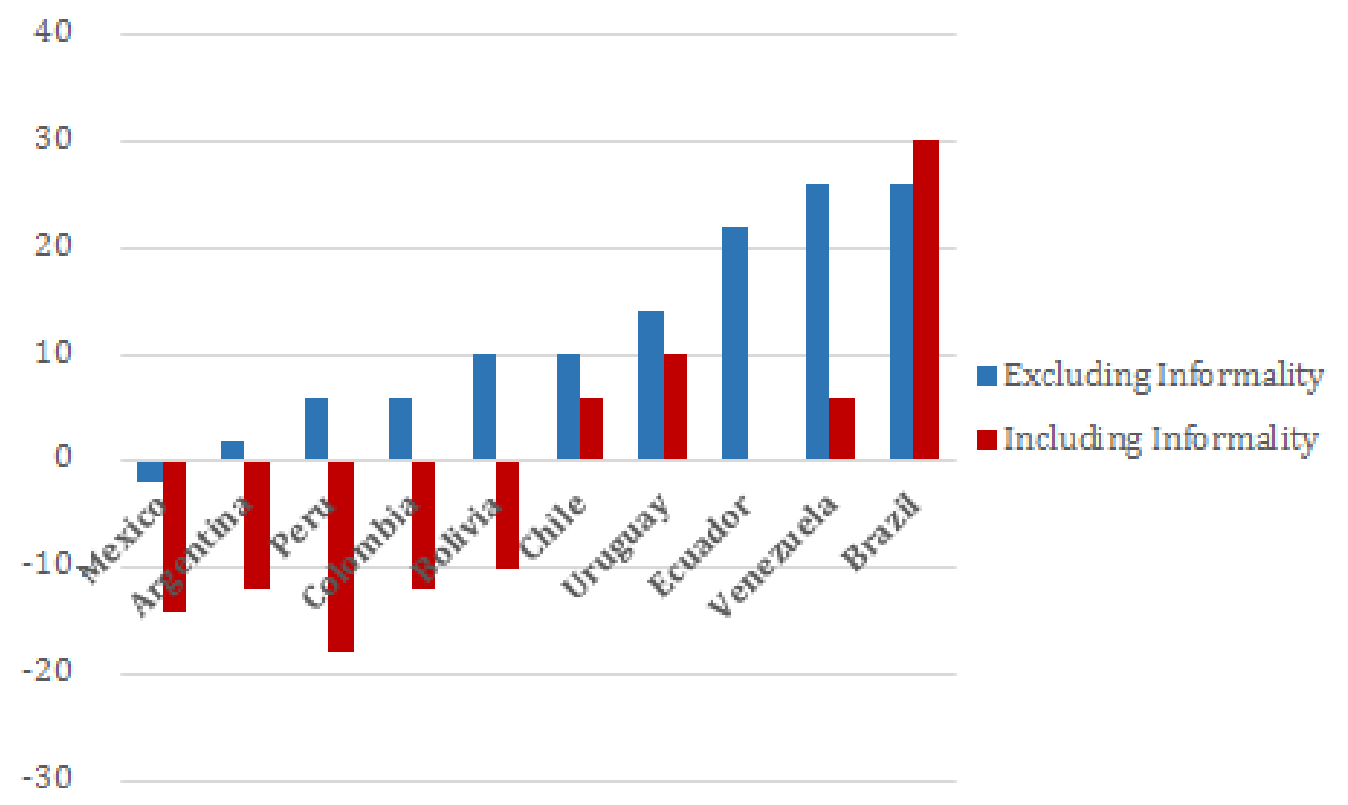

Source: Elaborated by the authors based on Alcántara (2012); Albala, A. (2009); Altman \& Castiglioni (2009); Fish and Kroenig (2009); Nohlen (2005); O'Connell (1999); Paine (2007); PNUD (2004); Shugart and Carey (1992). Datasets: OPAL (http://americo.usal.es/oir/opal/indicadores.htm);USAL(http://americo.usal.es/oir/opal/indic adores.htm);

CEPAL (http://estadisticas.cepal.org/cepalstat/WEB_CEPALSTAT/estadisticasIndicadores.asp?idioma= e); OIT (1998, 2012) and Latinobarometro (http://www.latinobarometro.org/).

Note: Negative values indicate majoritarian tendencies while positive values indicate consensualism.

We can see that, with the exception of Brazil ${ }^{15}$, the values decrease considerably once informality is included into the assessment. If informality is excluded, almost all countries display a consensual tendency during the 1990s. By contrast, informality produces majoritarian tendencies in Argentina, Peru, Colombia, Bolivia and Chile. In the Mexican case, majoritarian tendencies are further enhanced by informal factors. The average sum of all five variables excluding informality for our ten cases is 15.5 (out of a maximum of 25 ) or $12 \%$ above the mean value - hence, clearly within the consensual area. Once informality is included, the average score amounts to 12.2 , which is slightly below the mean value.

${ }^{15}$ In the case of Brazil, the fact that informal practices strengthen the legislature vis-à-vis the executive raises the score for the third variable and leads to a slight overall increase of consensual patterns. 
For the second period, we obtain a similar picture. Again, as it was expected, the values excluding informality are significantly higher and generally within the positive (consensual) area. Including informality, the values for six countries turn negative, pointing to more majoritarian patterns. While the average scores (including and excluding informality) decreased slightly from the first period to the second, there are significant shifts in some countries, already observed in section one. On the one hand, Venezuela, Uruguay and Bolivia moved clearly towards majoritarianism; on the other, Colombia and Argentina show a tendency towards consensualism. In the cases of Brazil, Chile and Ecuador, consensualism decreased on a smaller scale, whereas Mexico and Peru show a slight tendency towards consensualism - or rather, a reduced degree of majoritarianism when including informality. While these shifts are largely identical whether excluding or including informality, the majoritarian traits are stronger when informality is included.

Figure 03. Consensual and majoritarian tendencies during the 2000s (deviation from the midpoint of the scale, in percent)

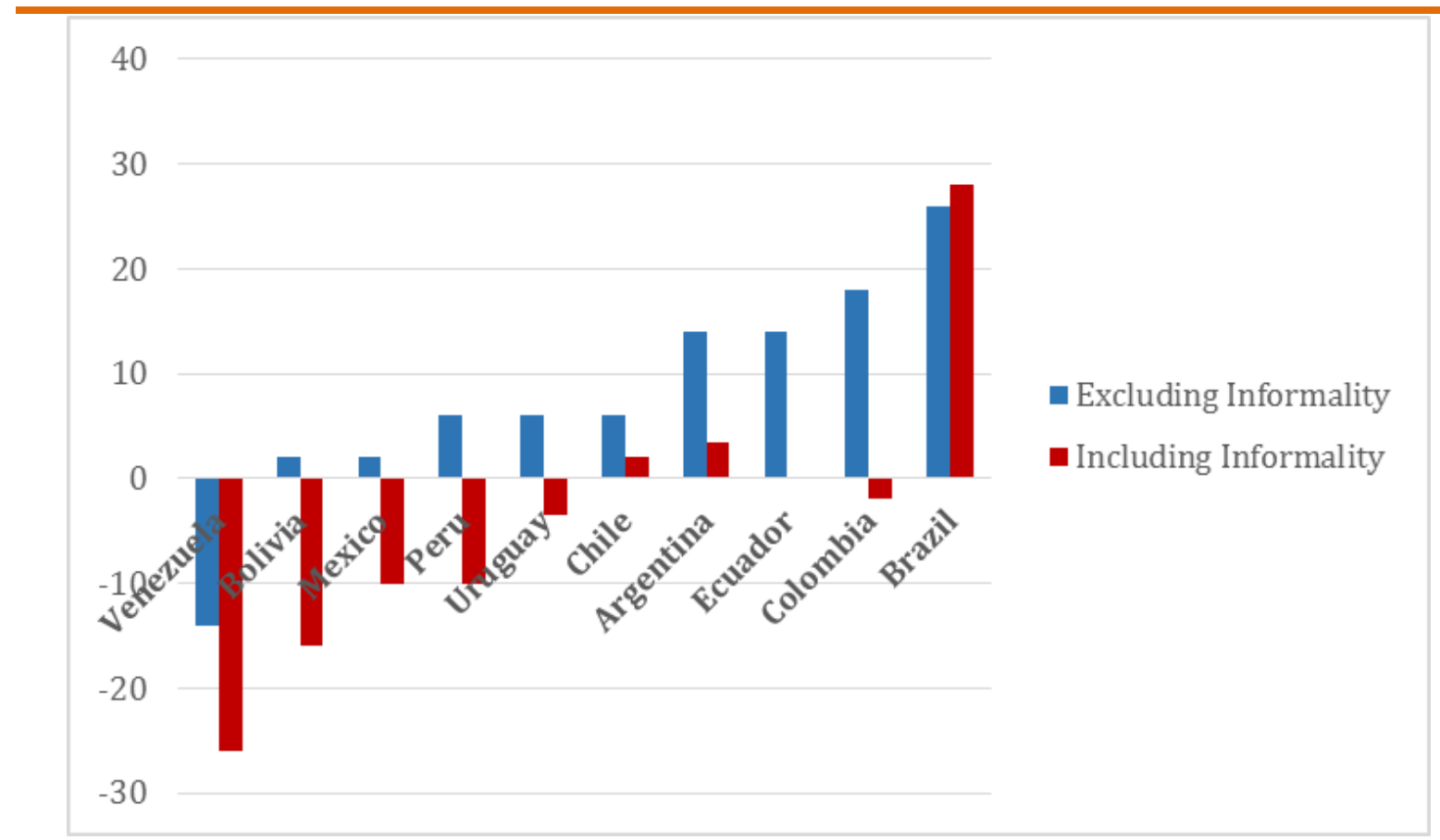

Source: Elaborated by the authors based on Alcántara (2012); Albala, A. (2009); Altman \& Castiglioni (2009); Fish and Kroenig (2009); Nohlen (2005); O'Connell (1999); Paine (2007); PNUD (2004); Shugart and Carey (1992). Datasets: OPAL (http://americo.usal.es/oir/opal/indicadores.htm);USAL(http://americo.usal.es/oir/opal/indic adores.htm);

CEPAL (http://estadisticas.cepal.org/cepalstat/WEB_CEPALSTAT/estadisticasIndicadores.asp?idioma= e); OIT $(1998,2012)$ and Latinobarometro (http://www.latinobarometro.org/). 
How, then, can these observations be related to the emergence of break-in parties?

\section{Break-in-parties and patterns of democracy}

Lijphart $(1999,2012)$ considered his patterns of democracy as largely stable and as independent variables that condition certain policy outcomes. As we have seen so far, institutional patterns are less stable in Latin America. Significant shifts occurred over the past 20 years in both directions, from consensualism to majoritarianism and vice versa. A closer look at the five variables we assessed for our sample reveals that variable three (legislative-executive relations) and four (electoral systems) remained more stable, while variables one (party systems) and two (executive power sharing) display greater variations. Variable five takes an intermediate position with regard to variation. As the first two variables with the strongest variation are highly correlated, the observed overall shift in the patterns of democracy can be attributed to changes in the party system. The structure of the party system influences power-sharing in the executive: a hegemonic party system leads to one party government, while a fragmented party system tends to produce multi-party cabinets and parliamentary coalitions.

Therefore, the structure of the party system and, by extension, the emergence and success of break-in parties, can be regarded as an important factor in the development of democratic patterns in Latin America. Party system changes were triggered in the 1990s by a crisis of legitimacy and large-scale dealignment. Institutional instability was reflected by high levels of electoral volatility, widespread protest, military coups and splits within established parties (DOMINGUEZ, 1997; MAINWARING et al., 2006). Break-in parties, many of them founded already several years or even decades earlier (see annex), emerged in the middle of this conjuncture of crisis and party system instability, when several established party systems broke down (ROBERTS, 2012; SEAWRIGTH, 2006). Those favorable conditions are reflected in increasing vote shares for break-in parties like the Causa R, FREPASO or Frente Amplio. By the 2000s, such conditions had changed and the vote share of new parties declined significantly, reflecting the fact that many of them had failed to establish themselves durably within the party system. This development is prototypically exemplified by the 
Venezuelan Causa R that came close to winning the presidency in 1993 and declined thereafter to a mere 3\% in the parliamentary elections of 1998. On the other hand, a range of parties managed to take advantage of the changing political environment of the 1990s. The PT in Brazil and the Frente Amplio in Uruguay rose steadily during the 1990s and finally gained the presidency thanks to the window of opportunity provided by the prevailing crisis of representation. So, break-in parties took diverging paths of development and, correspondingly, we expect them to affect the party system in different ways.

In general, we would expect break-in parties to turn the party system more pluralistic and as a consequence to push the whole system in a more consensual direction. This assumption, however, turns out to be wrong in light of our sample. Break-in parties emerged in all the countries under scrutiny here, but more consensual patterns only developed in three out of ten countries, namely Mexico, Colombia and Argentina, while Venezuela, Uruguay, Bolivia, Ecuador and Chile moved in the opposite direction. Obviously, the kind of break-in party and its interaction with the institutional context influenced the resulting patterns of democracy. To approach an explanation of the different outcomes, we discuss the hypothesis formulated at the beginning of the article: If strong break-in parties established themselves in the party system but remained short of winning the presidency, they pushed the system towards consensualism. Conversely, break-in parties that gained the presidency produced more majoritarian traits.

Break-in parties favored consensualism during the 1990s and 2000s, when they turned into important actors but failed to win the presidency. This was the case in Venezuela, Uruguay and Brazil during the 1990s, when the highest degrees of consensualism could be observed in these countries, together with Ecuador, where a traditionally fragmented party system was in place. The Brazilian PT, a party founded at the end of the 1970s by members of an alternative union movement, was one of the main contenders for the presidency during the 1990s, but fell short of ultimate victory. In the course of its repeated contests for power, the party moderated its program and opened itself to broader electoral coalitions (SAMUELS, 2004). The structure of the party system, however, changed little with the ascendance of PT, given its already extreme degree of fragmentation. 
In the case of Argentina, the relationship between break-in parties and democratic patterns is somewhat ambiguous. In the mid-1990s, a break-in party FREPASO - made major inroads on the subnational level. In 1997 and 1999, it turned out as the strongest party on the national level, but only in an alliance with the traditional Unión Cívica Radical, thereby reinforcing rather than altering the bipolar pattern of competition that had prevailed since redemocratization. Its rise to the presidency coincided with the economic crisis of 2001, in the course of which the president resigned and the alliance that had brought him to power collapsed soon after (ABAL MEDINA, 2009). Thus, the rise of FREPASO had no significant influence on the party system. The observed shift towards consensualism was rather produced by splits within the dominant Peronist party. Hence, both Brazil and Argentina are cases where the impact of break-in parties on democratic patterns is not clearly recognizable.

A clearer picture is obtained in the cases of Venezuela and Uruguay. In Venezuela, break-in parties like Causa R and Movimiento al Socialismo (MAS) had their best showing in $1993^{16}$. This not only produced a more diverse party system, but also forced president Caldera to form a broad parliamentary coalition. As a consequence, balanced executive-legislative relations prevailed in this period, and the overall degree of consensualism was comparatively high. In Uruguay, governmental coalitions became a common practice after the rise of the Frente Amplio in the 1980s and 1990s. In this case, the coalitions were formed between the two traditional parties with the purpose of keeping the newcomers at bay. Consensualism faded, however, when the break-in parties of the 1990s collapsed (as the Causa R in Venezuela) or won the presidency (as the Frente Amplio in Uruguay).

In Mexico, strongly majoritarian patterns prevailed during the 1990s, due to the still dominant role of the Partido Revolucionario Institucional (PRI). A shift towards consensualism occurred with the emergence of the Partido de la Revolución Democratica (PRD), and especially after 2000, when the PRI lost power to its long time rival, the Partido Acción Nacional (PAN). Polarization grew strongly in 2006, when the leftist PRD came close to winning the presidency. Its eventual failure can be seen as one

16 The latter case, the MAS, is somewhat ambiguous because the party had had a modest, but firm place within the party system since the mid-1970s. 
reason for the subsequent development towards more consensual patterns ${ }^{17}$. In Colombia, consensualism increased in the second period of observation, too. This shift was produced mainly by the first variable - the ENPP rose from 2.7 during the 1990s to 7.2 in the following decade. This rise, however, cannot be attributed to break-in parties, but rather to the disintegration of the two traditional parties. The most notable case of a break-in party in Colombia, the M-19, created by former guerrilla fighters, had only limited and short-term success at the start of the $1990 \mathrm{~s}^{18}$.

Therefore, while break-in parties in Argentina and Brazil did not alter significantly the structure of the party system, developments in Venezuela and Uruguay during the 1990s, as well as in Mexico during the 2000s, confirm the first part of our hypothesis: when strong break-in parties established themselves in the party system but fell short of winning the presidency, they pushed the system towards consensualism, mainly through their impact on the first two variables. Conversely, we assume that democratic patterns turned more majoritarian when break-in parties gained the presidency. This assumption holds for the cases of the Movimiento Quinta República (MVR) in Venezuela, the Frente Amplio in Uruguay (after 2004), the Cambio 90 in Peru and the MAS in Bolivia.

When new parties like Cambio 90 in Peru gained power in the 1990s, a strong tendency towards majoritarianism is observable in Figure 02, especially when taking informality into account. In the Peruvian case, however, this tendency is due less to shifts in democratic patterns than to authoritarian tendencies under the presidency of Alberto Fujimori ${ }^{19}$. During the 2000s, the ascendance to power of the Venezuelan MVR, the Uruguayan FA and the Bolivian MAS expressed itself in a shift towards majoritarianism from the first period to the second (Figure 01). In the Bolivian case, only variables one and two were affected by this development. In Uruguay, the shift concerned variables one, two and four. While power concentration in the party system and the executive was due to the dominant role of the FA after 2004, the shift in variable four is an artifact of the method of calculation - a slightly higher degree of electoral

${ }^{17}$ A first step in this direction was taken immediately after the election in 2006. After his narrow electoral victory, PAN-candidate Felipe Calderón made a coalition offer to the main parties in congress. Meanwhile, parliamentary alliances appear as an established practice in Mexico. 18 The M-19 reached its maximum voting in 1991 with 10.3\%. In 1994, it declined to 3.0\%. 19 Strong shifts towards majoritarianism can be caused by authoritarian tendencies of power concentration, too. Therefore, especially in Latin America, we have to differentiate carefully between shifting democratic patterns and changes in democratic quality. 
disproportionality in legislative elections led to a disproportional rise of the geometric mean.

By contrast, in Venezuela all five variables showed a strong tendency towards majoritarianism. The impact of Chavista hegemony stretched beyond the party system and the executive. The new constitution of 1999, alongside with the oil boom and the persistent moves to concentrate power in the hands of Hugo Chávez, affected the executive-legislative relations, the electoral system and the system of interest mediation - and even dimension two, which is not covered here ${ }^{20}$. In this case, again, the question arises if Lijphart's $(1999,2012)$ framework is still an adequate instrument to describe such development. Although institutional instability is a common feature in the region, the exceptional extent of the shift observed in Venezuela stands out in relation to all other cases and seems hardly compatible with Lijphart's $(1999,2012)$ assumption of (relatively) stable democratic patterns. The development in Venezuela, therefore, is better described in terms of democratic quality rather than democratic patterns equally as in Peru during the 1990s. Similar developments could also be observed in Ecuador, where the rise of Rafael Correa's Alianza País led to a strong shift towards majoritarianism. This shift is not fully expressed in the data because Correa assumed the presidency only in 2007.

In general, these cases show that break-in parties produce more majoritarian traits once they gain the presidency. This effect is amplified by the institutional context, especially by informal patterns like clientelism and the informal power resources on the president's side. The clientelistic nature and the high volatility of the party system intensify the dynamics that bring break-in parties to power. Once they get close to winning the presidency, voters flock to them in the hope to bet on the winning horse. While programmatic parties maintain their core constituency even in adverse times, clientelistic parties fall into rapid decline as soon as they lose their grip on power and fail to deliver material exchange to votes. Their constituency deserts to the prospective winners as it happened to the once all-powerful Venezuelan Acción Democrática in the second half of the 1990s. This dynamic intensifies the majoritarian character and the winner-takes-all logic of the electoral contest.

${ }^{20}$ The constitution of 1999 abolished the second legislative chamber. In the course of the 2000s, decentralization was reverted and institutional checks and balances abolished. 
Another factor that favors majoritarian tendencies is the dominant role of the president in the political system. Albeit formally balanced, the relationship between executives and legislatures in Latin America is tilted strongly towards the executive due to informal power resources of sitting presidents. This imbalance further reinforces the winner-takes-all logic and leads to strong polarization, especially when break-in parties (and, with them, new elites) come close to power. From this moment, they confront a united opposition, mainly of established actors that find themselves pushed aside. This was exactly what happened in Venezuela, Bolivia and Uruguay, where polarization grew - dramatically, in the former two cases - with the rise to power of the MVR, the MAS and the FA, respectively. Furthermore, unstable voting patterns and coattail effects often endow break-in parties with legislative majorities. As shown in Table 01, the ENPP declined sharply in Venezuela, Bolivia and Uruguay in the second period due to a new concentration of parliamentary votes. As a consequence, there was no need for executive power sharing, and the system turned even more majoritarian in its character. An exception to this rule is Brazil, where consensual patterns remained intact despite the PT winning the presidency in 2002. This is due to the extremely fragmented and regionalized party system and the fact that the PT remained far from a legislative majority even after Lula da Silva's resounding reelection in 2006. The example of Brazil suggests that our hypothesis has to be modified in the following sense: If successful break-in parties encounter a strongly consensual context, the shift towards majoritarianism is reduced or delayed. Even Hugo Chávez in Venezuela needed almost ten years to complete his hegemonic project and to remove the last traits of consensualism that had prevailed during the $1990 \mathrm{~s}^{21}$. However, the tendency of successful break-in parties to produce a polarized party system and majoritarian tendencies is confirmed by several cases in our sample - partly even by Brazil, where polarization has been on the rise in recent years.

\section{Conclusion}

The object of this article was the relationship between the emergence of breakin parties and the patterns of democracy in Latin America in the period between 1990

21 The end point of the consolidation of Chavista hegemony can be located around the year 2009, when presidential term limits were abolished in a referendum. A year before, a new governmental party had been founded, which aimed at centralizing control over the Chavista movement.

(2016) 10 (1) - $\quad$ - e0004-25/31 
and 2009. For this purpose, we applied the first five indicators of Lijphart's $(1999,2012)$ framework to ten Latin American countries by adapting them to the regional context. The measurement showed significant variation in democratic patterns, both synchronically, between our ten cases, and diachronically, from the 1990s to the 2000s. The inclusion of informal factors like clientelism and informal employment into the measurement produced more majoritarian patterns and even stronger variations. A closer look at the disaggregated results revealed that the strongest variations occurred in the first two variables, that is, the party system and executive power sharing that were supposedly most directly affected by the rise of new parties. However, the impact of break-in parties on democratic patterns appeared far from uniform. Our point of departure was the following hypothesis: If strong break-in parties established themselves in the party system but failed to gain the presidency, they pushed the system towards consensualism. Conversely, break-in parties that gained the presidency produced more majoritarian traits.

It could be shown by a closer look at the individual cases and variables that, indeed, break-in parties produced more majoritarian patterns once they had won the presidency. We also found confirming cases for the assumption that break-in parties favored consensualism as long as they fell short of winning the presidency. The Mexican PRD and the Venezuelan Causa R are fitting examples that show how the emergence of a break-in party produces more consensual patterns in variables one and two. Although there were also deviant cases like Colombia - where consensualism increased without the emergence of significant new parties -, the impact of break-in parties on the patterns of democracy remained sufficiently clear to confirm the hypothesized relationship. Still, this relationship depends strongly on contextual factors like the structure of party systems during the 1990s and 2000s. We, therefore, refrain from generalizing our observations beyond our sample and the specific period of observation. To do so would require more systematic comparison. Successful break-in parties of the 1990s have been by now occupying the presidency for a decade or more and it remains an open question whether this new situation of power concentration can again be modified by a new wave of break-in parties.

Revised by Cristiane Toledo Submitted in December 2014 Accepted in October 2015 


\section{References}

ABAL MEDINA, Juan (2009), The rise and fall of Argentine centre left: the crisis of Frente Grande and its internal causes. Party Politics. Vol. 15, № 03, pp. 357-375.

ABRANCHES, Sérgio Henrique Hudson de (1988), Presidencialismo de coalizão: o dilema institucional brasileiro. DADOS - Revista de Ciências Sociais. Vol. 31, № 01, pp. 05-34.

ALBALA, Adrián (2009), Coaliciones gobernamentales y régimen presidencial. Incidencia sobre la estabilidad política, el caso del Cono Sur (1983-2005). Documentos CIDOB America Latina. № 29. Fundación CIDOB.

ALCÁNTARA, Manuel (2012), Elections in Latin America 2009-2011: a comparative analysis. Working Paper. № 386. Kellogg Institute.

ALEMÁN, Eduardo and TSEBELIS, George (2011), Political parties and government coalitions in the Americas. Journal of Politics in Latin America. Vol. 03, № 01, pp. 0328.

ALTMAN, David and CASTIGLIONI, Rossana (2009), Gabinetes ministeriales y reformas estructurales en América Latina, 1985-2000. Revista Uruguaya de Ciencia Política. Vol. 18, № 01, pp. 15-39.

AMORIM NETO, Octavio and SAMUELS, David J. (2010), Democratic regimes and cabinet politics: a global perspective. RIEL - Revista Ibero-Americana de Estudios Legislativos. Vol. 01, № 01, pp. 10-23.

AMORIM NETO, Octavio (2009), O Brasil, Lijphart e o modelo consensual de democracia. In: Legislativo brasileiro em perspectiva comparada. Edited by INÁCIO, Magna and RENNÓ, Lucio R.. Belo Horizonte: Editora UFMG. pp. 105-131.

ARMINGEON, Klaus (2004), Institutional change in OECD democracies, 1970-2000. Comparative European Politics. Vol. 02, № 02, pp. 212-238.

CARDOSO, Adalberto Moreira (2001), A filiação sindical no Brasil. DADOS - Revista de Ciências Sociais. Vol. 44, № 01, pp. 0-0.

DOMINGUEZ, Jorge I. (1997), Latin Americas crisis of representation. Foreign Affairs. Vol. 76, № 01, pp. 100-114.

FISH, M. Steven and KROENIG, Matthew (2009), The handbook of national legislatures: a global survey. Cambridge: Cambridge University Press. 810 pp.

FLINDERS, Matthew V. (2010), Democratic drift: majoritarian modification and democratic anomie in the United Kingdom. Oxford: Oxford University Press. 325 pp.

FORTIN, Jessica (2008), Patterns of democracy? Counterevidence from nineteen postcommunist countries. Zeitschrift für Vergleichende Politikwissenschaft. Vol. 02, № 02, pp. 198-220. 
GALLAGHER, Michael (1991), Proportionality, disproportionality and electoral systems. Electoral Studies. Vol. 10, № 01, pp. 33-51.

HELMKE, Gretchen and LEVISTKY, Steven (2006), Informal institutions and democracy: lessons from Latin America. Edited by HELMKE, Gretchen and LEVISTKY, Steven. Baltimore: Johns Hopkins University Press. 368 pp.

KATZ, Richard S. and MAIR, Peter (1995), Changing models of party organization and party democracy: the emergence of the cartel party. Party Politics. Vol. 01, № 01, pp. 05-28.

KESTLER, Thomas; KRAUSE, Silvana, and LUCCA, Juan B. (2013), Los break-in parties en América Latina: éxito o fracaso? Revista Debates. Vol. 07, № 02, pp. 159-171.

KITSCHELT, Herbert (2000), Linkages between citizens and politicians in democratic polities. Comparative Political Studies. Vol. 33, № 06/07, pp. 845-879.

KITSCHELT, Herbert and WILKINSON, Steven I. (2009), Patrons, clients and policies: patterns of democratic accountability and political competition. Cambridge: Cambridge University Press. 342 pp.

LAAKSO, Markku and TAAGEPERA, Rein (1979), Effective number of parties: a measure with application to western Europe. Comparative Political Studies. Vol. 12, № 01, pp. 03-27.

LAUTH, Hans-Joachim (2012), Informal governance and democratic theory. In: International handbook on informal governance. Edited by CHRISTIANSEN, Thomas and NEUHOLD, Christine. Cheltenham: Edward Elgar Publishing. pp. 40-64.

LEVISTKY, Steven and ROBERTS, Kenneth M. (2011), The resurgence of the Latin American left. Edited by LEVISTKY, Steven and ROBERTS, Kenneth M.. Baltimore: Johns Hopkins University Press. 496 pp.

LIJPHART, Arend (2012), Patterns of democracy: government forms and performance in thirty-six countries. 2a Ed.. London/New Haven: Yale University Press. 368 pp.

LIJPHART, Arend (1999), Patterns of democracy: government forms and performance in thirty-six countries. 1ㅡㅡㄹ...London/New Haven: Yale University Press. 368 pp.

LIJPHART, Arend and CREPAZ, Markus M. (1991), Corporatism and consensus democracy in eighteen countries: conceptual and empirical linkages. British Journal of Political Science. Vol. 21, № 02, pp. 235-246.

LÓPEZ, Santiago (2005), Partidos desafiantes en América Latina: representacción política y estrategias de competencia de las nuevas oposiciones. Revista de Ciencia Política. Vol. 25, № 02, pp. 37-64. 
LORA, Eduardo (ed.) (2007), El estado de las reformas del Estado. Washington, D.C.: World Bank/Mayol Ediciones S.A.. 524 pp.

MAINWARING, Scott (1993), Presidentialism, multipartism, and democracy: the difficult combination. Comparative Political Studies. Vol. 26, № 02, pp. 198-228.

MAINWARING, Scott; BEJARANO, Ana María, and PIZARRO LEONGÓMEZ, Eduardo (2006), The crisis of democratic representation in the Andes. Stanford: Stanford University Press. 384 pp.

MAINWARING, Scott and SHUGART, Matthew S. (eds.) (1997), Presidentialism and democracy in Latin America. Cambridge: Cambridge Univ. Press. 508 pp.

MOLINA, Oscar and RHODES, Martin (2002), Corporatism: the past, present, and future of a concept. Annual Review of Political Science. Vol. 05, pp. 305-331.

MORGENSTERN, Scott and NACIF, Benito (eds.) (2002), Legislative politics in Latin America. Cambridge: Cambridge University Press. 528 pp.

NOHLEN, Dieter (2005), Elections in the Americas: a data handbook. Oxford: Oxford University Press. 758 pp.

NOLTE, Detlef and SCHILLING-VACAFLOR, Almut (eds.) (2012), New constitutionalism in Latin America: promises and practices. Farnham : Surrey/Burlington : VT: Ashgate. 490 pp.

O'CONNELL, Lesley (1999), Collective bargaining systems in 06 Latin American countries: degrees of autonomy and decentralization. Argentina, Brazil, Chile, Mexico, Peru, and Uruguay. Working Paper, № 399. Inter-American Development Bank. 46 pp.

PAINE, J. Mark (2007), Party systems and democratic governability. In: Democracies in development: politics and reform in Latin America. Edited by PAINE, J. Mark; ZOVATTO, Daniel G., and DÍAZ, Mercedes Mateo. Washington: Inter-American Development Bank, International Institute for Democracy and Electoral Assistance, David Rockefeller Center for Latin American Studies. pp. 149-177.

PNUD (2004), Programa de Naciones Unidas para el Desarrollo. La democracia en América Latina. Hacia una democracia de ciudadanas y ciudadanos. Buenos Aires: Ediciones Alfaguara. 288 pp.

POWELL, G. Bingham (2000), Elections as instruments of democracy: majoritarian and proportional visions. New Haven: Yale University Press. 298 pp.

POWER, Timothy J. (2010), Optimism, pessimism, and coalitional presidencialism: debating the institutional design of Brazilian democracy. Bulletin of Latin American Research. Vol. 29, № 01, pp. 18-33. 
REYNOLDS, Andrew (1999), Electoral systems and democratization in Southern Africa. Oxford: Oxford University Press. 341 pp.

ROBERTS, Kenneth M. (2012), Market reform, programmatic (de)alignment, and party system stability in Latin America. Comparative Political Studies. Vol. 20, № 10, pp. 01-31.

RUIZ VALERIO, José (2008), Coaliciones de gobierno bajo regímenes presidenciales: una aproximación a la experiencia latinoamericana. Espacios Públicos. Vol. 11, pp. 114141.

SAMUELS, David J. (2004), From socialism to social democracy: party organization and the transformation of the Workers' party in Brazil. Comparative Political Studies. Vol. 37, № 09, pp. 999-1024.

SANTOS, Fabiano (2000), Escolhas institucionais e transição por transação. Sistemas políticos de Brasil e Espanha em perspectiva comparada. Dados. Vol. 43, № 04.

SEAWRIGHT, Jason (2012), Party-system collapse. The roots of crisis in Peru and Venezuela. Palo Alto: Stanford University Press. 312 pp.

SHUGART, Matthew S. and CAREY, John (1992), Presidents and assemblies: constitutional design and electoral dynamics. New York: Cambridge University Press. 332 pp.

SIAROFF, Alan (1999), Corporatism in 24 industrial democracies: meaning and measurement. European Journal of Political Research. Vol. 36, pp. 175-205.

TAAGEPERA, Rein and GROFMAN, Bernard (1985), Rethinking Duverger's law: predicting the effective number of parties in plurality and PR systems - parties minus issues equals one. European Journal of Political Research. Vol. 13, № 04, pp. 341-352.

VATTER, Adrian (2008), Vom extremtyp zum normalfall? Die schweizerische konsensusdemokratie im wandel: eine re-Analyse von Lijpharts studie für die Schweiz von 1997 bis 2007. Swiss Political Science Review. Vol. 14, № 01, pp. 01-47.

VATTER, Adrian; FLINDERS, Matthew, and BERNAUER, Julian (2013), A global trend toward democratic convergence? A Lijphartian analysis of advanced democracies. Comparative Political Studies. Vol. 20, № 10, pp. 01-27. 


\section{Annex}

\section{Break-in parties according to the period of foundation}

Break-in parties founded during the 1960s and Break-in parties founded during the 1980s and 1970s $1990 \mathrm{~s}$

\begin{tabular}{l}
\hline ANAPO (COL) \\
ANAPO - Alianza Nacional Popular (COL) \\
CDC - Comunidad Democrática Cristiana (BOL) \\
CID - Coalición Institucionalista Demócrata \\
(ECU) \\
Conservadores Rojistas (ANAPO) (COL) \\
FA - Partido Frente Amplio (URU) \\
FRB - Frente de la Revolución Boliviana (BOL) \\
FVP - Federación Velasquista de Pichincha \\
(ECU) \\
ID - Izquierda Democrática (ECU) \\
LCR - La Causa R (VEN) \\
Liberales Rojistas (ANAPO) (COL) \\
Movimiento Al Socialismo (VEN) \\
MPD - Movimiento Popular Democrático (ECU) \\
MRL (Línea Dura) (COL) \\
MRLdP (COL) \\
PCCh - Partido Comunista de Chile (CHI) \\
PRA - Partido Revolucionario Auténtico (BOL) \\
PS-1 - Partido Socialista Uno (BOL) \\
UDP - Unidad Democrática y Popular (BOL)
\end{tabular}

AD/M-19 - Alianza Democrática M-19 (COL)

Alianza PLRE/FRA (ECU)

Alianza TJE - Alianza Trabajo, Justicia y

Educación (ARG)

C90 - Cambio 90 (PER)

CONDEPA - Consciencia de Patria (BOL)

CONDEPA-MP (BOL)

FADI - Frente Amplio de Izquierda (ECU)

FREPASO - Frente para un país solidario (ARG)

IU - Izquierda Unida (BOL)

IU - Izquierda Unida (PER)

MAS - Movimiento al Socialismo (BOL)

MBL - Movimiento Bolivia Libre (BOL)

MNRI - Movimiento Nacionalista

Revolucionario de Izquierda (BOL)

MUPP-NP - Movimiento Unidad Plurinacional

Pachakutic - Nuevo País (ECU)

MVR - Movimiento V República (VEN)

PPD - Partido por la Democracia (CHI)

PRE - Partido Roldosista Ecuatoriano (ECU)

PT - Partidos dos Trabalhadores (BRA)

PV - Proyecto Venezuela (VEN)

UCeDe - Unión del Centro Democrático (ARG)

Source: Own elaboration based on an expert survey. 